\title{
A produção escrita em turmas heterogêneas de português língua estrangeira
}

\section{The production written in heterogeneous classes of Portuguese foreign language}

\author{
Hellen Margareth Pompeu de SALES ${ }^{1}$ \\ (Universidade Federal do Pará UFPA) \\ José Carlos Chaves da CUNHA ${ }^{2}$ \\ (Universidade Federal do Pará UFPA)
}

\begin{abstract}
RESUMO: Apresentamos aqui os primeiros resultados de uma pesquisa-ação na qual experimentamos uma abordagem de ensino-aprendizagem da produção escrita que leva explicitamente em conta a heterogeneidade linguístico-cultural do público alvo. Nossa hipótese é a de que o trabalho docente e discente em turmas heterogêneas é favorecido quando se associa uma concepção de ensino-aprendizagem acional a uma concepção de língua-linguagem sócio interacionista. Nossos dados foram constituídos por 35 aulas de Português Língua Estrangeira ministradas a uma turma onde estavam presentes dez línguas-culturas diferentes - e pelos textos escritos pelos alunos. O progresso constatado entre as produções iniciais e as finais destes, assim como os resultados que obtiveram nos exames do Celpe-Bras ${ }^{3}$ são indícios significativos de que esta abordagem pode ajudar na superação das dificuldades inerentes à heterogeneidade do público alvo.
\end{abstract}

PALAVRAS-CHAVE: Heterogeneidade linguístico-cultural. Plurilinguísmo. Pluriculturalismo. Tarefas.

ABSTRACT: This paper presents preliminary results of an action research about the teaching and learning of writing with an approach which explicitly considers the cultural and linguistic diversity of the students. The work was based on the hypothesis that the teachers and learners actions can be facilitated when the concepts of action-oriented approach and of language in a socio-interactionist approach are combined. Data consists of 35 Portuguese as a foreign language classes, in which students coming from 10 different cultures and languages were present, and by these students written texts. Progress shown when initial and final productions of students are compared, as well as their results in the Celpe-Bras proficiency exam, are significant and allow the conclusion that this approach can help students overcome the difficulties generated by the diversity of the class.

KEY WORDS: Linguistic and cultural diversity. Multilingualism. Multiculturalism. Tasks.

\section{INTRODUÇÃO}

Temos hoje no Brasil vários cursos de Português Língua Estrangeira (PLE) cujos aprendentes são alocados em turmas heterogêneas ${ }^{4}$ do ponto de vista linguístico-cultural, isto é, em

\footnotetext{
1 Doutoranda em Letras (Linguística) no PPG de Letras da Universidade Federal do Pará. Professora Colaboradora do Plano Nacional de Formação de Professores - Universidade Federal do Pará. E-mail: hellenpompeu@yahoo.com.br

${ }^{2}$ Doutor em Ciências da Linguagem - Université de Toulouse II - Le Mirail. Docente na Universidade Federal do Pará. E-mail: jcccunha@gmail.com

${ }^{3}$ Celpe-Bras: Certificado de proficiência em língua portuguesa para estrangeiros. A aprovação nesse exame é indispensável para que estudantes estrangeiros possam cursar uma universidade no Brasil.

4 Toda turma de aprendentes é heterogênea, se levarmos em conta que cada indivíduo é um universo complexo. Porém, para este trabalho, chamamos de turmas heterogêneas aquelas que comportam diversas línguas/culturas.
}

(C) Revista Moara, n.42, jul.-dez. 2014, Estudos Linguísticos. ISSN 2358-0658 (Impresso).

Programa de Pós-Graduação em Letras / Universidade Federal do Pará. Todos os direitos reservados 
turmas compostas de usuários de diferentes línguas maternas, segundas e/ou estrangeiras. Essas turmas têm se expandido devido, principalmente, a programas como o PEC-G ${ }^{5}$. De acordo com o edital do programa, podem nele se inscrever estudantes de 52 países oriundos da África, Ásia, Oceania ${ }^{6}$, América Latina e Caribe ${ }^{7}$.

Essa expansão, no entanto, não tem sido acompanhada de uma formação suscetível de preparar os professores para lidar com turmas compostas por alunos de diferentes nacionalidades, usuários de várias línguas-culturas e com culturas educativas muitas vezes bastante diferentes da nossa; nem, tampouco, de pesquisas mais diretamente voltadas para os efeitos produzidos por essa heterogeneidade nas aulas de LE e/ou para o desenvolvimento e experimentação de materiais didáticos, procedimentos, estratégias que tornem mais eficaz a intervenção do professor e a aprendizagem dos alunos ${ }^{8}$. Parecemos ignorar que o ensino de LE no Brasil tem sido quase sempre realizado com turmas homogêneas do ponto de vista da língua-cultura materna dos alunos e que o aumento substancial do número de turmas heterogêneas do ponto de vista das línguas-culturas dos aprendentes é, para nós, um fenômeno relativamente recente que merece receber mais atenção, em nossas IES, tanto no âmbito da pesquisa, quanto no da formação de professores.

De fato, diferentemente de uma turma homogênea (do ponto de vista linguísticocultural), uma turma heterogênea é uma espécie de "caldeirão linguístico-cultural" no qual diferentes línguas-culturas estão entrelaçadas. Os aprendentes dessas turmas falam, além de sua LM (ou L1), uma ou várias línguas segundas e/ou estrangeiras. Isto impacta, evidentemente, os tipos de relações e de interações entre alunos e professor(es) na sala de aula, como ilustra a figura a seguir? ${ }^{9}$.

\footnotetext{
${ }^{5}$ O PEC-G seleciona estrangeiros, entre 18 e 25 anos, com ensino médio completo, para realizar estudos de graduação no país. O Programa foi desenvolvido pelos ministérios das Relações Exteriores e da Educação, em parceria com universidades públicas - federais e estaduais - e particulares.

(Fonte: http://portal.mec.gov.br/index.php?Itemid=530id=12276option=com_contentvimost).

6 África do Sul, Angola, Argélia, Benin, Cabo Verde, Camarões, China, Costa do Marfim, Egito, Gabão, Líbano, Gana, Índia, Marrocos, Mali, Namíbia, Moçambique, Paquistão, Nigéria, Rep. Dem. do Congo, Quênia, S. Tomé e Príncipe, Rep. do Congo, Síria, Senegal, Tanzânia, Tailândia, Togo, Timor Leste, Tunísia.

7 Antígua e Barbuda, Argentina, Barbados, Bolívia, Chile, Colômbia, Costa Rica, Cuba, El Salvador, Equador, Guatemala, Guiana, Haiti, Honduras, Jamaica, México, Nicarágua, Panamá, Paraguai, Peru, Rep. Dominicana, Suriname, Trinidad e Tobago, Uruguai, Venezuela.

${ }^{8} \mathrm{Na}$ realidade, há alguns estudos interessantes sobre o fenômeno da heterogeneidade linguístico-cultural realizados no Brasil. São pesquisas: a) de cunho histórico, que procuram, por exemplo, entender a situação linguística, cultural e/ou educacional em zona de fronteira. Ex.- Behares, Luis (2003); b) de cunho sociolinguístico, voltadas para o processo de ensino-aprendizagem de LE língua portuguesa materna e não materna. Ex.- Bagno, M. Gagné, G. Stubbs, M. (2002); Pessoa, M. (2011); c) de cunho intercultural. Ex. Lima (2011).

${ }^{9}$ Nesta figura, elaborada por Hellen Pompeu (2013), a(s) L/C1 que representa(m) a(s) língua(s)-cultura(s) dos aprendentes dialoga $(\mathrm{m})$ com $\mathbf{L} / \mathbf{C} 2$ (que é $\mathbf{L} / \mathbf{C}$ alvo - aqui o Português), com a L/C3 (que é a do professor podendo ou não ser a $\mathbf{L} / \mathbf{C}$ alvo) e, ainda, com a $\mathbf{L} / \mathbf{C} 4$ (que é(são) a(s) do(s) outro(s) estudantes). As setas mostram que esse procedimento não é uma via de mão única e que, nesse contexto, existe uma rede de interações onde todas as línguas-culturas podem interagir umas com as outras sem sobreposição ou justaposição de nenhuma delas.
} 
Figura 1- Representação da interação entre as línguas/culturas: L/C1 do aprendente; $\mathrm{L} / \mathrm{C} 2$ a alvo; L/C3 a do professor; $\mathrm{L} / \mathrm{C} 4 \mathrm{a}$ do(s) outro(s) aprendente(s)

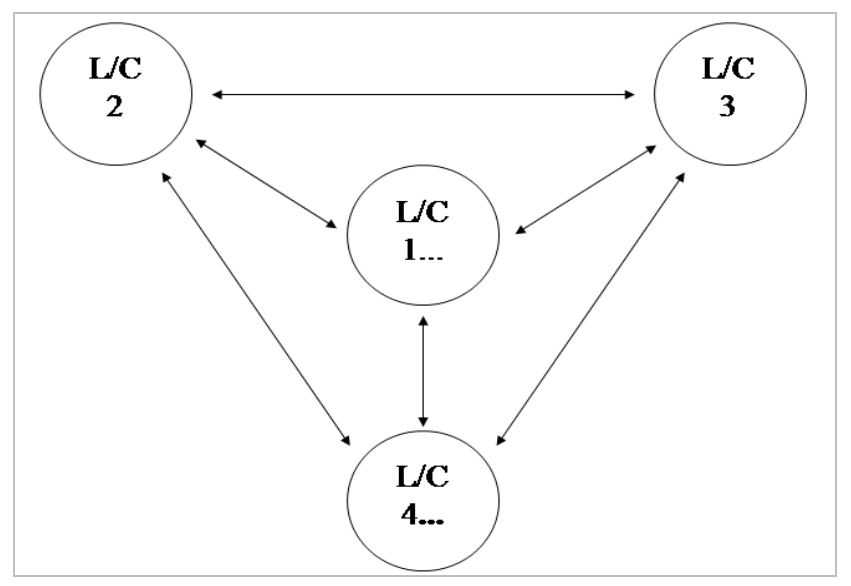

Nesse contexto, borbulham experiências diversas, entrelaçamentos, diálogos que são suscetíveis de favorecer o ensino-aprendizagem da língua-cultura alvo, mas também de provocar o fenômeno do choque cultural, outra característica de turmas heterogêneas que precisa ser tratada adequadamente.

No âmbito mais limitado desta investigação - que foca a produção escrita em turmas heterogêneas de PLE -, procuramos verificar se a complexidade desse ensinoaprendizagem pode ser equacionada quando o trabalho com gêneros textuais ${ }^{10}$ escritos é inserido em contextos significativos e têm o propósito de levar os aprendentes a agirem em situação real (ou simulada) de uso. Em outras palavras, procuramos aferir se o trabalho do docente e a aprendizagem dos discentes são favorecidos quando se associa uma concepção de ensino-aprendizagem acional - isto é, que considera os usuários e aprendentes de uma língua como atores sociais que cumprem tarefas em situações específicas - a uma concepção de língua-linguagem assentada no Interacionismo Sociodiscursivo (ISD).

\section{O interacionismo sociodiscursivo e o ensino-aprendizagem de línguas-culturas}

De acordo com Bronckart (1999, p.21), a expressão Interacionismo Social (IS) "designa uma posição epistemológica geral, na qual podem ser reconhecidas diversas correntes filosóficas e das ciências humanas" que aderem à tese segundo a qual "as propriedades específicas das condutas humanas são o resultado de um processo histórico de socialização". O principal representante do IS é Vygotsky (2002[1947]), psicólogo soviético que apresentou uma teoria de aquisição da linguagem, divulgada nos anos 70, reagindo contra os estudos inatistas e os de base positivista relacionados à linguagem.

A partir do IS, Jean-Paul Bronckart e sua equipe da Universidade de Genebra desenvolveram o Interacionismo Sociodiscursivo (ISD). Eles discutem, entre outras questões, as condições de produção dos $\operatorname{textos}^{11}$, de sua classificação e do seu

${ }_{10} \mathrm{Na}$ teoria do discurso de Bakhtin (1895-1975), que influenciou o Interacionismo Sociodiscursivo - ISD, uma língua só pode ser utilizada na forma de enunciados e que a capacidade linguageira não se manifesta por palavras, frases ou orações isoladas, mas por gêneros do discurso.

11 Para Bronckart (1999, p.75), os textos podem ser definidos como "toda unidade de produção de linguagem situada, acabada e autossuficiente (do ponto de vista da ação ou da comunicação)". 
funcionamento em um quadro teórico que entende as condutas humanas como ações significantes, cujas propriedades estruturais e funcionais são, antes de tudo, um produto da socialização (BRONCKART, 1999).

\subsection{As condições de produção textual e o ensino-aprendizagem}

Para Bronckart (1999), os parâmetros de produção textual estão relacionados com $a$ ação de linguagem, o intertexto e a situação de ação. A ação de linguagem pode ser definida em um nível sociológico, "como uma porção da atividade de linguagem do grupo, recortada pelo mecanismo geral das avaliações sociais e imputada a um organismo humano singular" (BRONCKART, 1999, p. 99); e um nível psicológico, "como um conhecimento disponível em um organismo ativo sobre as diferentes facetas da sua própria responsabilidade na intervenção verbal" (Idem). O intertexto é o conjunto de gêneros textuais ${ }^{12}$ elaborados por gerações e que são utilizados, e até transformados, de acordo com as novas formações sociais. Já a situação de ação pode ser definida como algumas representações dos mundos fisico, social e subjetivo (construídas pelo agente produtor do texto, de acordo com seu conhecimento, que podem influenciar a produção textual), que se mobilizam em duas direções distintas: ao contexto e ao conteúdo temático. Ver figura a seguir ${ }^{13}$.

Figura 2- Representação de uma Situação de ação bronckartiana.

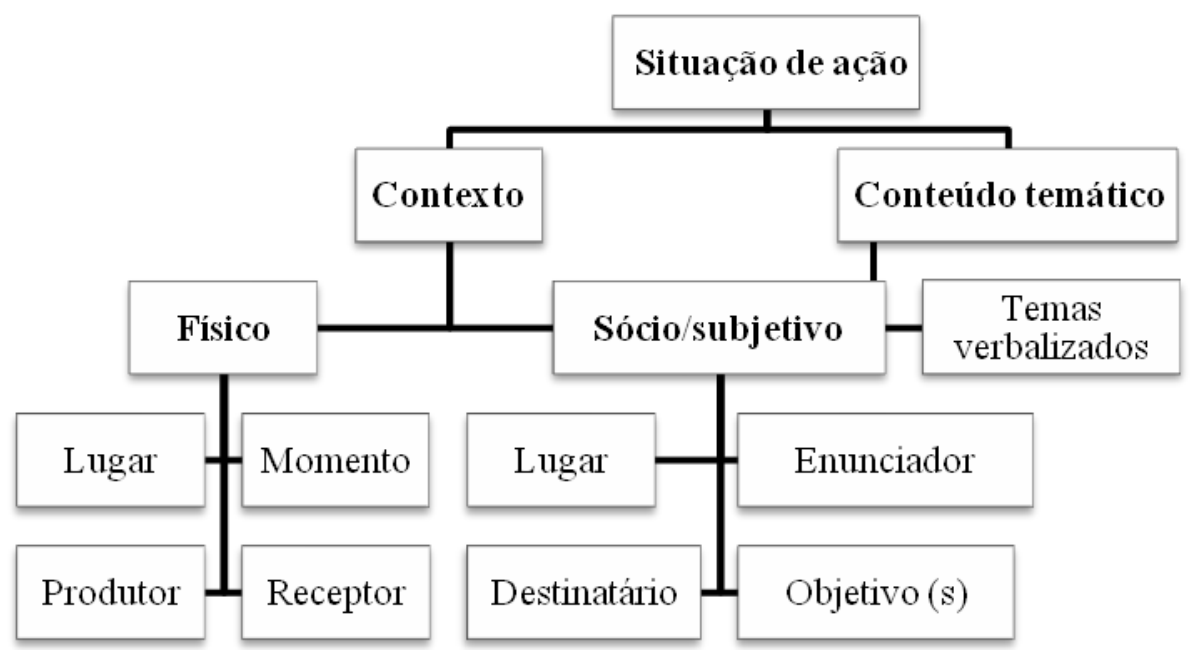

Segundo Bronckart (1999), o contexto é subdividido em dois planos, o físico e sócio/subjetivo, e está relacionado, sobretudo, com os fatores que exercem influências sobre a organização textual, como a situação na qual o agente se encontra.

O físico pode ser definido a partir do lugar, momento, emissor e receptor da produção textual, pois, segundo este pesquisador (1999, p. 93), "todo texto resulta de um

12 De acordo com Bronckart (1999), por serem os textos resultados da atividade humana, ligados às necessidades, interesses e condições de funcionamento das formações sociais, há características distintas que definem as múltiplas "espécies de texto", com características comuns, que são denominadas de gêneros de textos. ${ }^{13}$ Elaborada por Helen Pompeu (2013). 
comportamento verbal concreto, desenvolvido por um agente situado nas coordenadas do espaço e do tempo".

O sócio/subjetivo é constituído pelo lugar social, pela posição social do enunciador, pela posição social do destinatário e pelo objetivo da interação da produção textual visto que, para Bronckart (1999, p. 94), "a produção de todo texto inscreve-se no quadro das atividades de uma formação social, mais precisamente, no quadro de uma forma de interação comunicativa que implica o mundo social (normas, valores, regras etc.) e o mundo subjetivo (imagem que o agente dá de si ao agir)".

Em relação ao parâmetro do conteúdo temático - que tem relação com o(s) tema(s) que será/serão verbalizado(s) ao se produzir um texto -, Bronckart (1999) afirma que um texto pode ter como tema os fenômenos concernentes tanto ao mundo físico - "a descrição de um animal e da sua condição de vida, por exemplo" -, quanto ao mundo social - "discutir, por exemplo, valores utilizados por um grupo" (BRONCKART, 1999, p. 97) -, veicular temas mais subjetivos e, ainda, combinar temas referentes aos três mundos.

\subsection{A situação de ação e o contexto simulado}

A respeito da discussão, especificamente referente ao contexto, propomos - ao tratarmos de tarefas de produção escrita, em ambiente escolar - subdividi-lo em contexto real e contexto simulado. O contexto Real, proposto por Bronckart (1999), é aquele que traz aspectos referentes a uma dada situação real de produção textual, em qualquer ambiente possível; já o Simulado, proposto por nós, é aquele que, por vezes, ocorre na simulação de tarefas em ambiente escolar (e em outros, como no teatro, por exemplo), visto que ele também pode influenciar uma produção textual. Ver figura $1.2^{14}$.

Figura 3- Representação da nossa proposta de uma Situação de ação em relação ao contexto, acrescentando a noção de contexto simulado, na realização de tarefas de produção escrita, em ambiente escolar.

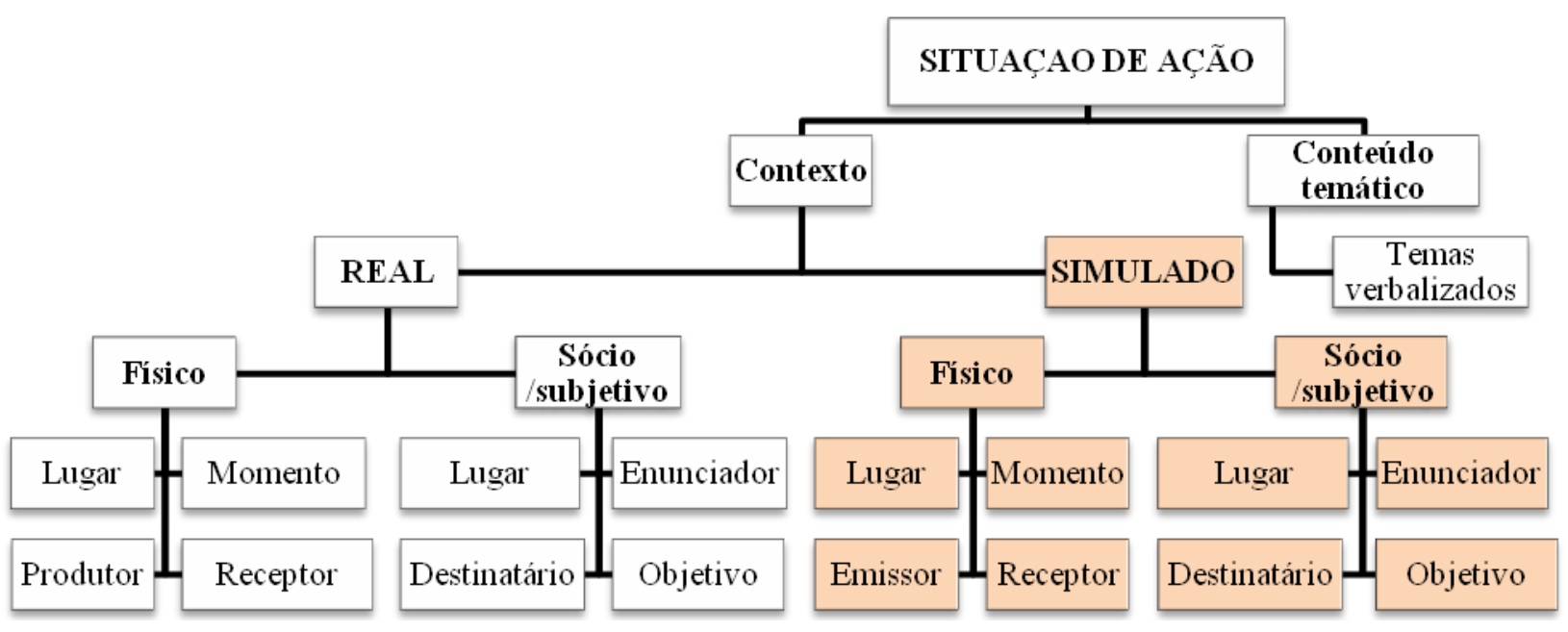

Nossa proposta de acrescentar ao parâmetro de contexto (situação de ação) o contexto simulado ocorre por entendermos que, ao produzir textos escritos em ambiente escolar, como os que analisamos nesta pesquisa, o aprendente ultrapassa sua condição de aluno (aquele que terá seu texto corrigido para receber uma nota), torna-se um aprendente/ator social/usuário da língua que cumpre tarefas sociais. Ao cumprir essas

${ }^{14}$ Elaborada por Hellen Pompeu (2013). 
tarefas $^{15}$ em ambiente escolar, ele precisa encontrar, além do seu papel social de aluno, outro, simulado, para cumprir tarefas impossíveis de serem efetivamente realizadas em sala de aula. É o que buscamos, quando procuramos associar a teoria do ISD a uma concepção de ensino-aprendizagem acional.

\section{A perspectiva acional e o ensino-aprendizagem de línguas-culturas}

A expressão Perspectiva Acional (PA) nasceu com o Quadro Europeu Comum de Referência para Línguas (QECRL) ${ }^{16}$, em 2001. A partir do que está exposto no segundo capítulo QECRL, podemos considerá-la como a orientação metodológica do documento:

A abordagem aqui adotada é, também de um modo muito geral, orientada para a ação, na medida em que considera antes de tudo o utilizador e o aprendente de uma língua como atores sociais, que têm que cumprir tarefas (que não estão apenas relacionadas com a língua) em circunstâncias e ambientes determinados, num domínio de atuação específico (CONSELHO DA EUROPA, 2001, p. 29).

Quando consideramos os alunos de uma língua como atores sociais que cumprem tarefas em determinado contexto, supomos que eles são, antes de tudo, utilizadores de uma língua-cultura. Assim, as tarefas que eles serão levados a cumprir não podem ser apenas linguageiras, nem limitadas ao domínio escolar, visto que, fora de sala de aula, eles são confrontados a um mundo onde precisam realizar ações em diversos contextos: cultural, esportivo, familiar etc.

\subsection{As tarefas}

Para o Conselho da Europa, uma tarefa é "qualquer ação com uma finalidade considerada necessária pelo indivíduo para atingir um dado resultado no contexto da resolução de um problema, do cumprimento de uma obrigação ou da realização de um objetivo" (CONSELHO DA EUROPA, 2001, p. 30). As tarefas são características da vida cotidiana e podem envolver um número maior ou menor de atividades linguísticas. Podemos comparar a ação na execução de uma tarefa com a realização de uma peça de teatro: os atores leem textos, memorizam, repetem etc.; o diretor prepara os atores etc.; os técnicos testam a luz, os cenários etc. Todos têm muitas atividades, mas a ação só se realiza verdadeiramente quando a peça é encenada. Acontece o mesmo na sala de aula: são feitos muitos exercícios e atividades, mas a finalidade é a realização da tarefa.

As tarefas podem ou não ser ligadas às ações linguageiras. Bérard (2009) afirma que conduzir um carro não é uma ação linguageira, mas para conhecer os códigos de trânsito ou para dialogar com o monitor de uma autoescola, por exemplo, é preciso efetuar ações linguageiras.

Contrariamente ao que creem muitos professores, uma tarefa pode não ser realizada na escola. Ela está diretamente ligada a uma ação que pode ser real ou simulada. Bérard (2009, p. 38) afirma que "as tarefas propostas na sala de aula não são todas idênticas àquelas da vida porque elas não têm desafio real, na maioria das vezes são simuladas, mas sua realização pode dar lugar a interações e a trocas comparáveis aos intercâmbios da vida real". Percebemos aqui, novamente, a necessidade de se levar em conta o contexto simulado

15 Ver a noção de tarefas na subseção Perspectiva Acional.

16 O QECRL é um documento descritivo, reflexivo e adaptativo elaborado pelo Conselho da Europa e publicado em 2001. Ele propõe, entre outros: planejamento de programas de ensino/currículos e certificações; elaboração de materiais didáticos; cooperação entre sistemas educacionais; promoção de abordagens plurilíngues e pluriculturais etc. 
da situação de ação, na produção de textos escolares.

A perspectiva acional considera ainda que, para a realização de tarefas, os aprendentes mobilizam diversas competências. Entre elas, destacam-se as comunicativas sociolinguísticas e pragmáticas, que estão relacionadas diretamente com um ensino plurilíngue e pluricultural.

\subsection{O plurilinguismo e o pluriculturalismo}

Antes da publicação do QECRL, estudiosos ${ }^{17}$ já discutiam questões referentes ao plurilinguismo e ao pluriculturalismo. No documento, diferencia-se pluri- de multi- por este último ser conhecido apenas como o conhecimento de várias línguas (multilinguismo) e/ou culturas (multiculturalismo). No âmbito do plurilinguísmo, não se considera a aprendizagem de uma língua estrangeira como se fosse a soma de uma competência para comunicar numa língua estrangeira com a competência para comunicar na língua materna, de forma compartimentada; pelo contrário, toma-se os aprendentes como indivíduos que possuem uma competência plurilíngue e pluricultural integrada.Para o Conselho da Europa, "O plurilinguismo tem que ser visto no contexto do pluriculturalismo, pois a língua não é apenas um aspecto fundamental da cultura, mas também um meio de acesso a manifestações culturais" (CONSELHO DA EUROPA, 2001, p. 25).

A Perspectiva Acional ressalta a importância da abordagem plurilíngue e pluricultural na formação de cidadãos/aprendentes/usuários de línguas, pois "à medida que a experiência pessoal de um indivíduo no seu contexto cultural se expande, [...], constrói-se uma competência comunicativa, para a qual contribuem todo o conhecimento e toda a experiência das línguas e na qual as línguas se inter-relacionam e interagem" (CONSELHO DA EUROPA, 2001, p. 23).

\subsection{As competências}

O QECRL distingue competências gerais de competências comunicativas. As primeiras são aquelas a que se recorre para realizar atividades de todo tipo, incluindo as linguísticas. No documento, elas aparecem como: Conhecimento declarativo - saber (conhecimento do mundo, conhecimento sociocultural, consciência intercultural); Capacidades e competência de realização - saber fazer (capacidades práticas, capacidades interculturais); Competência existencial - saber ser - saber estar (atitudes, motivações, valores, crenças, estilos cognitivos, traços de personalidade); Competência de aprendizagem - saber aprender (consciência da língua e da comunicação, consciência e capacidades fonéticas, capacidades de estudo, capacidades heurísticas). Já as competências comunicativas ${ }^{18}$ são aquelas que dão a possibilidade a um indivíduo de agir utilizando especificamente meios linguísticos. Elas são compostas pelas: Competência Linguística (lexical; gramatical; semântica; fonológica; ortográfica; ortoépica); Competência Sociolinguística (marcadores linguísticos de relações sociais, regras de polidez, expressões de sabedoria popular, diferenças de registro, dialetos e os sotaques); Competência Pragmática (discursiva e funcional). Para este estudo, interessam-nos mais as competências comunicativas.

De acordo com o Conselho da Europa (2001, p. 34), a competência linguística

17 Por exemplo, no mundo francófono, ROULET, E. (1980); COSTE, D. (1995); DABÈNE, L. e DEGACHE, C. éd. (1996); COSTE, D.; MOORE, D. e ZARATE, G. (1997) ; BILLIEZ, J. (1998).

18 A fim de realizar as intenções comunicativas, os utilizadores/aprendentes mobilizam as capacidades gerais [...] e combinam-nas com uma competência comunicativa mais especificamente relacionada com a língua (CONSELHO DA EUROPA, 2001, p. 156). 
Inclui os conhecimentos e as capacidades lexicais, fonológicas e sintáticas, bem como outras dimensões da língua enquanto sistema [...]. Esta componente [...] relaciona-se não apenas com a extensão e a qualidade dos conhecimentos (p. ex.: em termos da possibilidade de fazer distinções fonéticas ou da extensão e precisão do vocabulário), mas também com a organização cognitiva e o modo como este conhecimento é armazenado.

Já a competência sociolinguística está relacionada ao conhecimento e às capacidades necessárias para lidar com a dimensão social especificamente do uso da língua. Vejamos alguns exemplos desta ${ }^{19}$ :

- Marcadores linguísticos de relações sociais: Saudação (À chegada: Olá!, Bom Dia!...; Despedidas: Adeus!, Até já!...); Formas de tratamento (Oficial: Vossa Eminência...; Formal: O senhor, a senhora...); Exclamação (Meu Deus!) etc.

- Regras de polidez: Delicadeza positiva (Mostrar interesse pelo bem-estar de alguém; partilhar experiências...); Delicadeza negativa (Evitar comportamento ameaçador...); Falta de educação (brusquidão, franqueza excessiva...) etc.

- As expressões de sabedoria popular: Provérbios (Mais vale um pássaro na mão que dois voando...); Expressões familiares (Daqui até lá; vou ali e já venho;...); Expressões de crenças (Tempo: Em Abril, águas mil...) etc.

- As diferenças de registro (Oficial: Está aberta a sessão...)

- Os dialetos e os sotaques: O léxico (Madeirense - semilha por batata...)etc.

No QECRL (2001), as competências pragmáticas estão divididas em competência discursiva (como são organizadas, estruturadas e adaptadas as mensagens) e funcional (como as mensagens são utilizadas para a realização de funções comunicativas).

A competência discursiva trata da capacidade de organizar as frases coerentes em termos de tópico/foco; informação dada/informação nova; sequência natural; capacidade para estruturar e gerir o discurso em termos de: organização temática; coesão e coerência; ordenação lógica; estilo e registro; eficácia retórica. Esta competência pode ser relacionada com o princípio de cooperação ${ }^{20}$ e com o conceito de arquitetura do texto ${ }^{21}$. Este último está mais diretamente ligado a esta pesquisa visto que trata de convenções de organização de texto em determinadas línguas-culturas.

A competência funcional "diz respeito ao uso do discurso falado e aos textos escritos na comunicação para fins funcionais específicos" (CONSELHO DA EUROPA, 2001 p. 178).

Ao levarmos os alunos a desenvolverem habilidades de produção escrita, queremos familiarizá-los com a língua em uso. Por isso, durante nossas aulas no curso de PLE, as

\footnotetext{
19 Os exemplos fornecidos para o português não são universalmente aplicáveis e podem ou não ter equivalentes noutras línguas (CONSELHO DA EUROPA, 2001, p. 169).

20 "Dê a sua contribuição à medida que lhe for sendo pedida, no nível em que ocorre, pela finalidade ou sentido da troca conversacional em que está envolvido, observando as seguintes máximas: - qualidade (tente que a sua contribuição seja verdadeira); - quantidade (torne a sua contribuição tão informativa quanto necessário, mas não mais que isso); - relevância (não diga o que não for relevante); - modo (seja breve e organizado, evite a falta de clareza e a ambiguidade)" (GRICE 1975, apud, CONSELHO DA EUROPA, 2001, p. 175).

${ }^{21}$ Isto é, "o conhecimento das convenções de organização de um texto numa dada comunidade, por exemplo: o modo como a informação é estruturada na realização de várias macro funções (descrição, narração, exposição); o modo como são contados pequenos episódios, histórias, anedotas etc.; o modo como é construída uma argumentação (num debate, no tribunal etc.); o modo como os textos escritos (composições, cartas formais, etc.) são dispostos na página, são organizados em parágrafos e são sequenciados" (CONSELHO DA EUROPA, 2001, p. 175).
} 
competências, sobretudo a sociolinguística e a pragmática, não foram negligenciadas: a partir dos textos escritos produzidos pelos aprendentes, trabalhamos sistematicamente os conhecimentos destes em relação aos marcadores linguísticos de relações sociais, às regras de polidez, entre outros.

\section{O método}

Para a realização deste estudo utilizamos o método de pesquisa-ação que, de acordo com Ghedin e Franco (2008), é um tipo de pesquisa que deve originar-se de necessidades sociais reais e estar vinculada ao meio natural de vida, o que implica a participação dos sujeitos envolvidos no processo. Nela, atribui-se "ao pesquisador os papéis de pesquisador e de participante e [...] [sinaliza-se] para a necessária emergência dialógica da consciência dos sujeitos na direção de mudança de percepção e de comportamento" (GHEDIN; FRANCO, 2008, p. 216).

\section{$3.1 \mathrm{O}$ contexto}

A Pesquisa-ação ocorreu em uma turma heterogênea do ponto de vista linguístico-cultural de aprendentes do PEC-G, inseridos no curso de Português Língua Estrangeira - PLE, da Universidade Federal do Pará - UFPA, no ano de 2012. Segue o perfil da turma.

Quadro 1 - O perfil da turma

\begin{tabular}{|c|c|c|c|c|c|c|}
\hline & $\mathbf{N}^{\circ}$ & SUJEITOS & PAÍS & $\begin{array}{c}\text { L/C 1 } \\
\text { (Língua/ } \\
\text { Cultura 1) } \\
\end{array}$ & $\begin{array}{c}\text { L/C 2 } \\
\text { (Língua/ } \\
\text { Cultura 2) } \\
\end{array}$ & $\begin{array}{c}\text { L/CE } \\
\text { (Língua/Cultura Estrangeira) }\end{array}$ \\
\hline \multirow{8}{*}{ 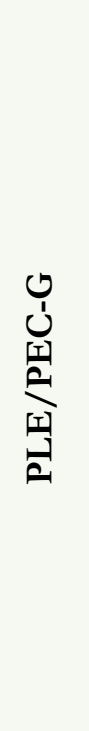 } & 01 & A1(aprendente1) & RDC & Lingala & $\begin{array}{l}\text { Kikongo, } \\
\text { Francês }\end{array}$ & Português \\
\hline & 02 & A2(aprendente2) & RDC & Lingala & $\begin{array}{l}\text { Kikongo, } \\
\text { Francês }\end{array}$ & Português \\
\hline & 03 & A3 (aprendente3) & Haiti & $\begin{array}{l}\text { Crioulo } \\
\text { Haitiano } \\
\end{array}$ & Francês & Inglês, Português \\
\hline & 04 & A4(aprendente4) & Jamaica & Inglês & - & Espanhol, Português \\
\hline & 05 & A5(aprendente5) & $\begin{array}{l}\text { Trinidad } \\
\text { Tobago }\end{array}$ & Inglês & $\begin{array}{l}\text { Crioulo de } \\
\text { Trinidad }\end{array}$ & Português, Espanhol \\
\hline & 06 & A6(aprendente6) & Cuba & Espanhol & - & Português \\
\hline & 07 & A7(aprendente7) & Cuba & Espanhol & - & Português \\
\hline & 08 & A8(aprendente8) & Cuba & Espanhol & - & Inglês, Português \\
\hline \multirow{4}{*}{ 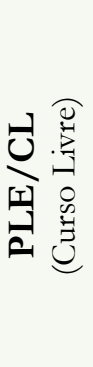 } & 01 & A9(aprendente9) & França & Francês & - & Inglês, Português \\
\hline & 02 & A10(aprendente10) & Holanda & Holandês & - & Inglês, Alemão, Português \\
\hline & 03 & A11(aprendente11) & Alemanha & Alemão & - & Inglês, Português \\
\hline & 04 & A12(aprendente12) & Suriname & Holandês & Sranantongo & $\begin{array}{l}\text { Inglês, Espanhol, } \\
\text { Português }\end{array}$ \\
\hline
\end{tabular}




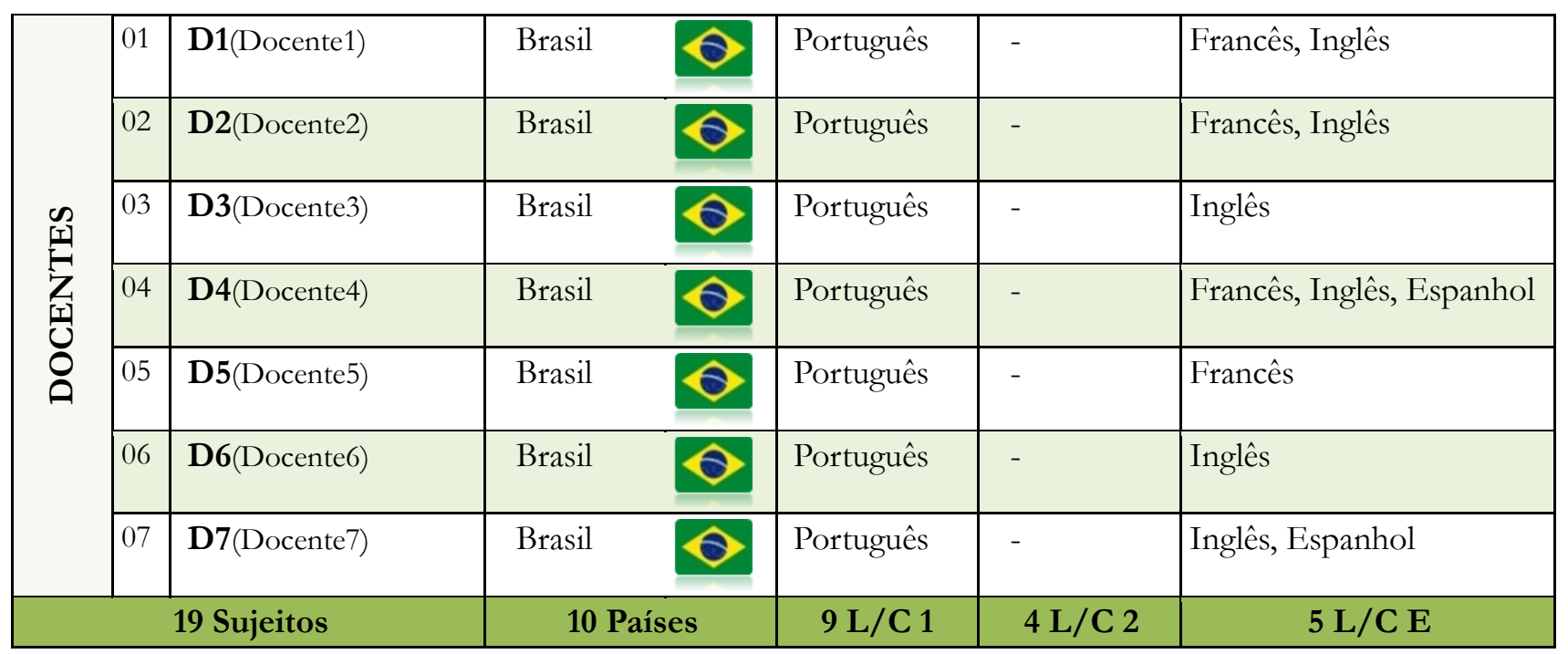

A turma foi constituída por 19 sujeitos participantes, oriundos de 10 países diferentes e falantes de diversas línguas-culturas: nove maternas; quatro segundas e cinco estrangeiras. Seu perfil foi apresentado aqui porque compreendemos que todos os sujeitos envolvidos influenciaram em algum momento e/ou de alguma maneira o processo de ensino-aprendizagem, embora nem todos tenham permanecido no grupo até o final do curso. Dos 19 sujeitos, restaram 11: quatro professores/monitores (D1, D5, D6 e D7), e sete aprendentes PLE/PEC-G (A1, A2, A3, A4, A6, A7).

\subsection{O corpus}

O corpus deste trabalho foi constituído, sobretudo, de produções textuais de gêneros da modalidade escrita da língua portuguesa como carta, e-mail, artigo de opinião etc. produzidos, durante as aulas de PE do curso de PLE, pelos aprendentes do PEC-G.

- Os instrumentos de constituição dos dados

Elaboramos e efetivamos na turma uma proposta para elaboração de tarefas. A partir dela, durante as aulas, os alunos desenvolveram tarefas de produção escrita, tanto em ambiente presencial de aprendizagem (sala de aula), quanto em ambiente virtual de aprendizagem.

- A seleção dos dados

Os critérios de seleção foram: 1) A Primeira Produção Escrita - PPE, da qual todos os aprendentes participaram; 2) A Última Produção Escrita - UPE, da qual todos os aprendentes participaram; 3) Todas as produções escritas, que ainda não haviam sido corrigidas pelo professor ${ }^{22}$.

Os itens 1) e 2) se justificam por servirem de método de comparação entre a primeira e a última produção escrita dos alunos, permitindo assim que verificássemos $o$ desenvolvimento da competência de PE dos alunos. O item 3) serviu para investigarmos a influência

22 Optamos pelas produções que ainda não tinham sido corrigidas pelo professor por acreditarmos que nelas encontraríamos, com mais facilidade, a influência das línguas-culturas dos aprendentes em seus textos. 
das línguas-culturas dos alunos em seus textos escritos para, em seguida, tentarmos dimensionar o impacto da beterogeneidade linguístico-cultural da turma para o ensino-aprendizagem de produção escrita em PLE.

- O Procedimento de análise dos dados

A análise incidiu sobre dois aspectos diferentes: 1) o desenvolvimento da PE dos alunos $^{23}$; 2) a verificação da influência da(s) língua(s)-cultura(s) em seus textos (a fim de tentar dimensionar o impacto da heterogeneidade linguístico-cultural da turma no ensino/aprendizagem da PE).

\subsection{A descrição da nossa proposta de elaboração de tarefas de produção escrita}

Com o objetivo principal de levar os aprendentes da turma heterogênea do ponto de vista linguístico-cultural de PLE a desenvolverem a competência de produção escrita, propusemos-lhes a realização de tarefas a partir de diversos gêneros textuais da modalidade escrita da língua portuguesa, tais como: carta do leitor, e-mail, artigo de opinião etc. Nossa proposta foi desenvolvida em três momentos.

a) Momento 1 (preparação para a tarefa de produção escrita)

Este primeiro momento familiariza o aluno com um determinado assunto, dandolhe condições de expor seu ponto de vista a respeito de um tema discutido e de conhecer os dos seus colegas. A ideia era a de elaborar tarefas que levassem em conta a heterogeneidade da turma; ou seja, que além de ajudarem os alunos a se expressarem oralmente em sala de aula- a partir da temática desenvolvida no(s) texto(s) propostos -, também os levassem a conhecer e a aceitar o outro. Três questões aqui orientaram nossa abordagem:

- O que não queríamos fazer nas tarefas?

Não queríamos que a turma conhecesse um determinado aluno apenas pelo olhar deste. Por isso excluímos atividades do tipo: Pesquise sobre a língua-cultura do sen colega. Esse tipo de atividade pode incentivar a criação de estereótipos a respeito de um determinado grupo e provocar o choque cultural em sala de aula. Mas também não queríamos sugerir atividades do tipo: - Fale sobre você, seu país, sua cultura etc., para que seu colega lhe conheça melhor. Esse tipo de atividade, muito comum em sala de aula, tanto de LE como de LM, nos pareceu superficial para um trabalho com a turma heterogênea e não permitia que o aluno expusesse e defendesse seu ponto de vista sobre um determinado assunto.

- O que queríamos fazer nas tarefas?

\footnotetext{
23 Para esta análise, nos baseamos nas competências comunicativas apresentadas pelo QECRL (2001) - em conjunto com os critérios de avaliação propostos pelo exame Celpe-Bras (acrescentando, porém os itens em negrito) - visto que os aprendentes, sujeitos desta pesquisa, realizariam o exame ao final do curso de PLE. Observamos: $\mathrm{Na}$ Adequação ao contexto (Ação-gênero, Interlocutor, Propósito, Tese, Argumentos, Proposta de intervenção) - se o aprendente cumpriu os propósitos de leitura e escrita solicitados na tarefa; $\mathrm{Na}$ Adequação ao discurso (coesão e coerência) - a qualidade com que a ação foi desenvolvida. De acordo com o Celpe-Bras, a "adequação discursiva avalia se o texto tem a consistência necessária para cumprir o propósito da tarefa em questão e se as informações estão em consonância com o gênero discursivo proposto pela tarefa" (BRASIL, 2013a, p.8); Na Adequação linguística - (o léxico, a gramática e a influência das línguas-culturas), a frequência dos desvios linguísticos nos textos.
} 
Queríamos que, além de dominar um assunto tratado na aula, se expressar oralmente e, claro, produzir textos escritos coerentes, o aluno também pudesse conhecer melhor seus colegas. Pensamos que ele poderia conhecer o outro, através do outro. Em outras palavras: eu mesmo, enquanto aluno, discuto a respeito da minha própria língua-cultura a partir de um determinado assunto exposto em um determinado texto. Assim, os problemas de criação de estereótipos, de categorização etc. poderiam ser mais bem trabalhados. Essa sugestão é congruente com a abordagem Intercultural discutida por Abdallah-Pretceille (2003), que critica a formação intercultural baseada em estereótipos que generalizam determinados grupos.

- O que fizemos nas tarefas?

Optamos por levar os alunos a conhecerem o outro de forma indireta, a partir de discussões sobre determinados assuntos. Temas como Tatuagem, Educação financeira, Idosos no mercado de trabalho etc. foram tratados em sala de aula e os aprendentes relacionaram esses temas com as suas próprias culturas. Era também nosso objetivo, neste primeiro momento, prepará-los para a tarefa de produção escrita (momento 2).

b) Momento 2 (realização da tarefa de produção escrita)

Este segundo momento foi dividido em três etapas: descobrir o que o aluno já conhecia a respeito do gênero a ser trabalhado; levá-lo a conhecer bem o funcionamento do gênero escolhido e a produzir seu primeiro texto escrito.

Neste momento observamos, nos textos escritos, a influência constante das L/C dos alunos que ora se apresentava como um desvio linguístico, ora como uma inadequação de uso.

c) Momento 3 (o ajuste na produção escrita)

No terceiro momento, cada aluno foi convidado a fazer ajustes necessários na sua produção escrita, em um ambiente virtual de aprendizagem (www.aprendentesple.com.br ${ }^{24}$ ). O objetivo era melhorar a produção escrita do aluno e estimular o trabalho em grupo já que, na plataforma virtual, os aprendentes tinham a oportunidade de aperfeiçoar seus textos iniciados em sala de aula e de ajudar os colegas com dificuldades de escrita. $\mathrm{Na}$ realidade, a partir da criação do site, todos os envolvidos passaram a assumir mais suas responsabilidades no processo de ensino/aprendizagem. Aliás, os textos por eles postados também serviram de dados para a nossa análise.

\section{$4 \quad$ A análise}

Primeiramente trataremos do desenvolvimento da PE dos alunos e, em seguida, da influência da(s) língua(s)-cultura(s) em seus textos (o impacto da heterogeneidade linguístico-cultural da turma no ensino/aprendizagem da PE)

24 Partindo do pressuposto de que a internet pode ser um elemento facilitador/mediador no ensino/aprendizagem de línguas, decidimos criar a plataforma virtual aprendentesple (idealizada por Hellen Pompeu e programada pelo doutorando em Engenharia elétrica Washington Sousa). Mais informações no artigo APRENDENTESPLE : Plataforma virtual no ensino-aprendizagem da produção escrita em Português Língua Estrangeira-PLE (POMPEU; SOUSA, 2013). 


\subsection{O desenvolvimento da produção escrita}

Para ilustrar esta análise, mostraremos apenas os textos do A1 (Primeira e Última produção escrita), porém, os dos demais alunos também foram analisados.

A Primeira Produção Escrita é uma simulação de uma Carta do Leitor, realizada em ambiente escolar de sala de aula, no dia 08 de maio de 2012, durante uma aula de PE. O contexto Simulado (Sócio subjetivo) ${ }^{25}$ é o seguinte:

- O lugar de produção: Qualquer um imaginado pelo produtor do texto, por exemplo: a empresa, a escola, a casa etc.;

- A posição do emissor / enunciador: Leitor da revista ISTOÉ;

- A posição do receptor /destinatário: A Jornalista que escreven o texto "Tatuagem não tem idade", Patrícia Diguê; a revista IstoÉ el ou o público em geral;

- O objetivo: Escrever uma Carta do Leitor, a ser enviada à revista IstoÉ, posicionandose contrária ou favoravelmente as informacões do texto "Tatuagem não tem idade", publicado na revista pela jornalista Patrícia Diguê, Edição: 2135, do dia 08 de Outubro de 2011.

A Última Produção Escrita é uma simulação de um texto para ser publicado em um blog. Ela foi realizada em ambiente virtual de aprendizagem - no site aprendentesple -, no período de 21/09 a 04/10/12, em horário indefinido, durante o curso de PLE. O contexto simulado (Sócio subjetivo) é:

- O lugar de produção: Qualquer um imaginado pelo produtor do texto, por exemplo: a empresa, a escola, a casa etc.;

- A posição do emissor / enunciador: Membro do grupo de apoio aos obesos;

- A posição do receptor / destinatário: Membros de um grupo de apoio aos obesos e/ on os internautas de um modo geral;

- O objetivo: Escrever um texto para ser publicado em um Blog, posicionando-se contrária ou favoravelmente à Agência Nacional de Vigilância Sanitária - ANVIS A de proibir a venda de inibidores de apetite.

\begin{tabular}{|c|c|c|c|}
\hline \multicolumn{2}{|r|}{ PPE-A1 } & \multicolumn{2}{|r|}{ UPE- A1 } \\
\hline & Belém, 08 de maio de 2012 & 01 & URGENTE!!! NOSSA SIBUTRAMINA EM \\
\hline 02 & Cara SenhoraPatríciaDiguê & 02 & AMEAÇA \\
\hline & Eu li com muita atenção sua artigo sobre & 03 & Postado por: $\mathrm{xx}$ \\
\hline & tatuagem o titulo "Tatuagem não tem idade" & 04 & 28 de setembro de 2012 \\
\hline 05 & publicado na revista ISTOE em 13/10/10. & 05 & Sexta \\
\hline 06 & argumentar em pouco sobre a questao & 06 & Olá Pessoal! \\
\hline 07 & eva homens e mulheres & 07 & itado \\
\hline 08 & ejo de ta & 08 & $\mathrm{~m}$ \\
\hline 09 & Eu acho que o preconceito tatuage & 09 & ANVISA. Que absurdo pessoal! \\
\hline 10 & de hoje mas é um antigo preconceito antes & 10 & Esse produto nos ajuda muito a emagrecer. \\
\hline 11 & mesmo o nascimento de Cristo, mas & 11 & erder 10 quilos, sem precisar \\
\hline 12 & atualmente o fenomeno tatuagem tem uma & 12 & gastar tanto dinheiro na cirurgia. A ANVISA \\
\hline 13 & significadona cada epoca do povo e um maior & 13 & interpreta má a evidência científica. Se \\
\hline 14 & parte no modo de vida que muda o dia-a-dia e & 14 & tivéssemos ainda uma boa memória, nos \\
\hline 15 & na cada ambiente de & 15 & lembraríamos que o mesmo caso ocorreu em \\
\hline 16 & que tem uma tatuagem & 16 & janeiro de 2010 com a agência europeia que \\
\hline
\end{tabular}

25 Apresentamos aqui apenas o contexto simulado sócio subjetivo porque não é possível identificar nos textos o contexto simulado físico. 
estava por exemplo prisioneiro, escravos ou tenha hepatite, uma pessoa perigosa na comudade mas hoje no globo há muito dos jovens do que os velhos e o modo de vida dos jovens influença o modo de vida dos velhos e dos meninos e os preconceitos religea, idade estavam perdindo, hoje a pessoa faz tatuagem para simple razão de parecer muita bonita na sua ambiente.

Além disso tem também uma problema de higienizado, quais são dos equipamentos usam para realizar esta tatuagem, o que é que respondam na tudo condiça higienica? Eu penso, quem tem que fazer uma tatuagem deve pensar a primera sobre a questão de equipamentos não apenas satisfazer seu desejo mas pensa também sobre os efeitos desasfasteres sobre os equipamentos. Atenciosamente, Cara Patrícia Diguê. $\mathrm{Xx}$

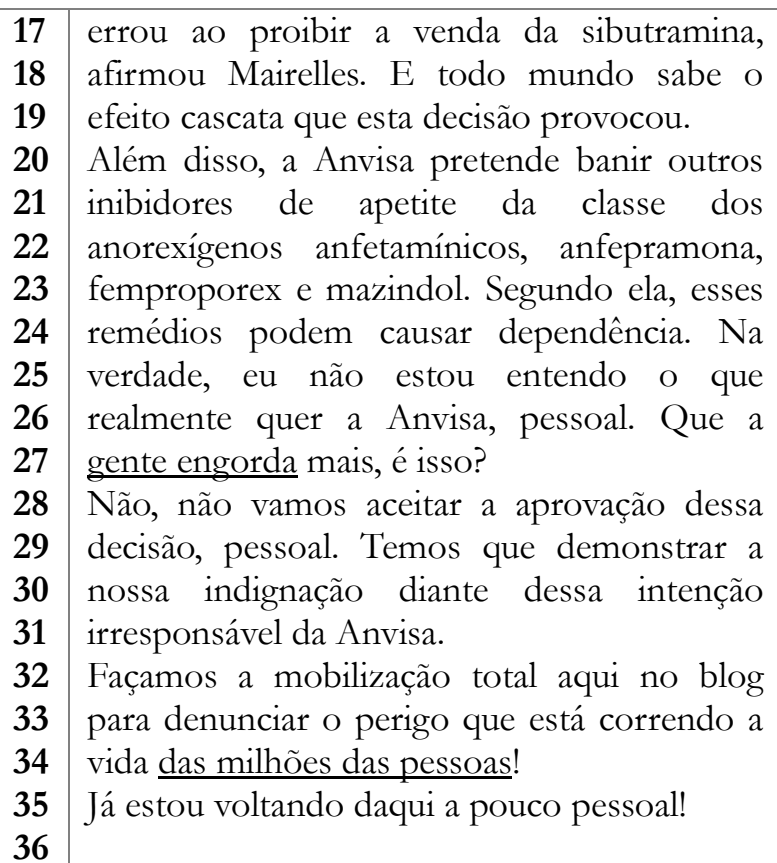

Em relação à Adequação contexto - na PPE, percebemos que o A1 inicia seu texto apresentando os elementos paratextuais do gênero (data - 01, vocativo - $\mathbf{0 2}$, assinatura - 36...) e dirige-se diretamente a seu INTERLOCUTOR, embora logo o abandone, "Cara Senhora Patrícia Digue" (02); "Eu li com muita atenção sua artigo..." (03). O aluno ignora o propósito da tarefa e não se posiciona nem favoravelmente, nem contrariamente ao texto da autora. Ele anuncia outro propósito "o que leva homens e mulheres a realizarem, na maturidade, o desejo de tatuar a pele?" (07-08), que também não é desenvolvido. Não há TESE, nem ARGUMENTOS, nem proposta de INTERVENÇÃO, condizentes com aquilo que escreve. O que ocorreu no texto do A1 foi percebido nas demais produções escritas dos outros aprendentes.

Já na UPE é possível observar que o $\mathbf{A} \mathbf{1}$ foi além dos elementos paratextuais (0106...) e praticou a AÇÃO de escrever um texto para um blog. Ele interagiu bem com seus INTERLOCUTORES indiretos (Internautas - 06...), alcançando o seu PROPÓSITO de argumentar a respeito da intenção da ANVISA de proibir a venda de inibidores de apetite. Ele opta por se posicionar contrariamente à intenção da agência (07-09...), com a TESE de que "Esse produto nos ajuda muito a emagrecer" (10); utilizando como ARGUMENTOS a situação de que a ANVISA já errou outras vezes em proibir os medicamentos e que " $A$ ANVIS A interpreta má a evidência científica" (12-14). Ele finaliza seu texto com uma proposta de INTERVENÇÃO: "Façamos a mobilização total aqui no blog para denunciar o perigo que está correndo a vida das milhões das pessoas!" (33-35). No texto do A1, podemos perceber que, para cumprir sua tarefa, o aluno consegue simular uma situação na qual se vê como um ator social que realiza uma tarefa/ação da vida real, mesmo em ambiente escolar, como propõe a perspectiva acional. O posicionamento do aluno em relação à ANVISA é apontado desde o título: - "URGENTE!!! NOSSA SIBUTRAMINA EM AMEAÇA” (01-02). Ele mostra que não vai apenas concordar/discordar com o autor do texto, mas agir em uma situação como se realmente fizesse parte dela. Mostra-se à vontade para discuti-la e utiliza um vocabulário que evidencia claramente seu posicionamento: - "Estou irritado de saber pelo jornal dessa madrugada da proibição da Sibutramina pela ANVISA. Que absurdo pessoal!” (07-09). 
Quanto à Adequação ao discurso ${ }^{26}$, na PPE, o A1 discorre sobre vários assuntos relacionados ao tema tatuagem (preconceito - 09; higiene dos equipamentos- 27-28), mas de forma desordenada. Ele também não utiliza elementos coesivos que possam evitar repetições "Eu acho que o preconceito TATUAGEM...(09); Antes uma pessoa que tem uma TATUAGEM...(16);...hoje a pessoa far. TATUAGEM...(23);...para realizar esta TATUAGEM (27)...". A falta de uma sequência lógica e de elementos coesivos necessários no texto do A1 contribuiu para a falta de clareza e objetividade no texto. A mesma situação ocorreu com os textos dos demais alunos. Na UPE, foram percebidos poucos problemas referentes ao discurso. Um deles se deu quando o autor anunciou o nome Mairelles (18) sem nenhuma contextualização prévia, como se o leitor já soubesse de quem se tratava. Porém, de um modo geral, o texto está mais organizado e os elementos coesivos aparecem com mais frequência:...proibição da Sibutramina (08) - Esse produto nos ajuda muito a emagrecer (10);... A ANVISA (12-13) - a agência europeia...(17);...proibir a venda da sibutramina (1718) - esta decisão(19-20)... a Anvisa (21)- Segundo ela (24)...

$\mathrm{Na}$ Adequação Linguística ${ }^{27}$, na PPE - foram percebidos no texto do A1 desvios lexicais (Atençao (03), titulo (04), questao (06), fenomeno (12), epoca(13) etc.); gramaticais (Sua artigo (03), vou argumentar_em pouco (06), está de hoje (09-10), antes mesmo o nascimento (10-11), na cada epoca (13) etc.) e a Influência das línguas-culturas do aluno (Influença (21), simple (24) etc.). Na UPE, foram percebidos poucos desvios linguísticos (agente engorda (28); a vida das milhões das pessoas! (34-35)) e não percebemos a Influência das linguas-culturas do aluno. Os textos dos demais alunos também não apresentaram muitos problemas de adequação linguística.

Analisando os textos da PPE dos sete alunos, percebemos que a maioria deles se limitou apenas a apresentar a opinião sobre tatuagem, ignorando o comando da questão, ou a concordar com a autora, copiando trechos do texto de apoio de forma aleatória. Partindo do princípio de que o exame Celpe-Bras considera "que, mesmo que apresente coesão e adequação linguística, a produção será julgada como inadequada se não cumprir o que foi solicitado na tarefa" (BRASIL 2013, p.7), considerando que os alunos não cumpriram completamente a PPE.

Se considerarmos que, em um ensino acional, o objetivo da aprendizagem não é apenas levar o aluno a conhecer a estrutura de uma língua, mas sobretudo levá-lo a utilizar essa língua a fim de realizar tarefas, podemos afirmar que a UPE foi cumprida com sucesso pelos alunos. Aliás, convém lembrar que as tarefas são ações necessárias que os indivíduos realizam para atingir um objetivo (CONSELHO DA EUROPA, 2001); e, ainda, um convite para agir no mundo usando a linguagem com compromisso social (BRASIL, 2010b).

\subsection{A heterogeneidade linguístico-cultural (a influência das línguas-culturas)}

Além dos aspectos tratados na subseção anterior, também buscamos analisar mais especificamente, a Influência da língua-cultura dos em suas produções escritas, observando a língua em uso. Para ilustrar esta análise utilizaremos um texto do A7, motivado pela tarefa "RIO OU SALVADOR" (Celpe-Bras 2009/1):

Você é gerente de uma agência de viagens e foi consultado por um cliente sobre opções de pacotes para passar o Carnaval no Brasil. Com base nas informações do texto, escreva um e-mail de resposta ao seu cliente, sugerindo o destino mais apropriado ao perfil dele. Seu texto deverá apresentar duas alternativas (Rio e Salvador), fazer a referência ao perfil do cliente a argumentar a favor de um dos destinos.

26 O QECRL (2001) usa a expressão Competência discursiva.

27 O QECRL (2001) usa a expressão Competência linguística. 
Trata-se de uma simulação de um e-mail resposta realizada em ambiente escolar de sala de aula, durante uma aula de PE. O contexto simulado (Sócio subjetivo) é o seguinte:

- O lugar de produção: Qualquer um imaginado pelo produtor do texto, por exemplo: a empresa, a escola, a casa etc.;

- A posição do emissor / enunciador: gerente de uma agência de viagens;

- A posição do receptor/destinatário: cliente da agência de viagens;

- O objetivo: escrever um e-mail de resposta ao seu cliente, sugerindo o destino mais apropriado ao seu perfil.

Segue o texto escrito pelo A7.

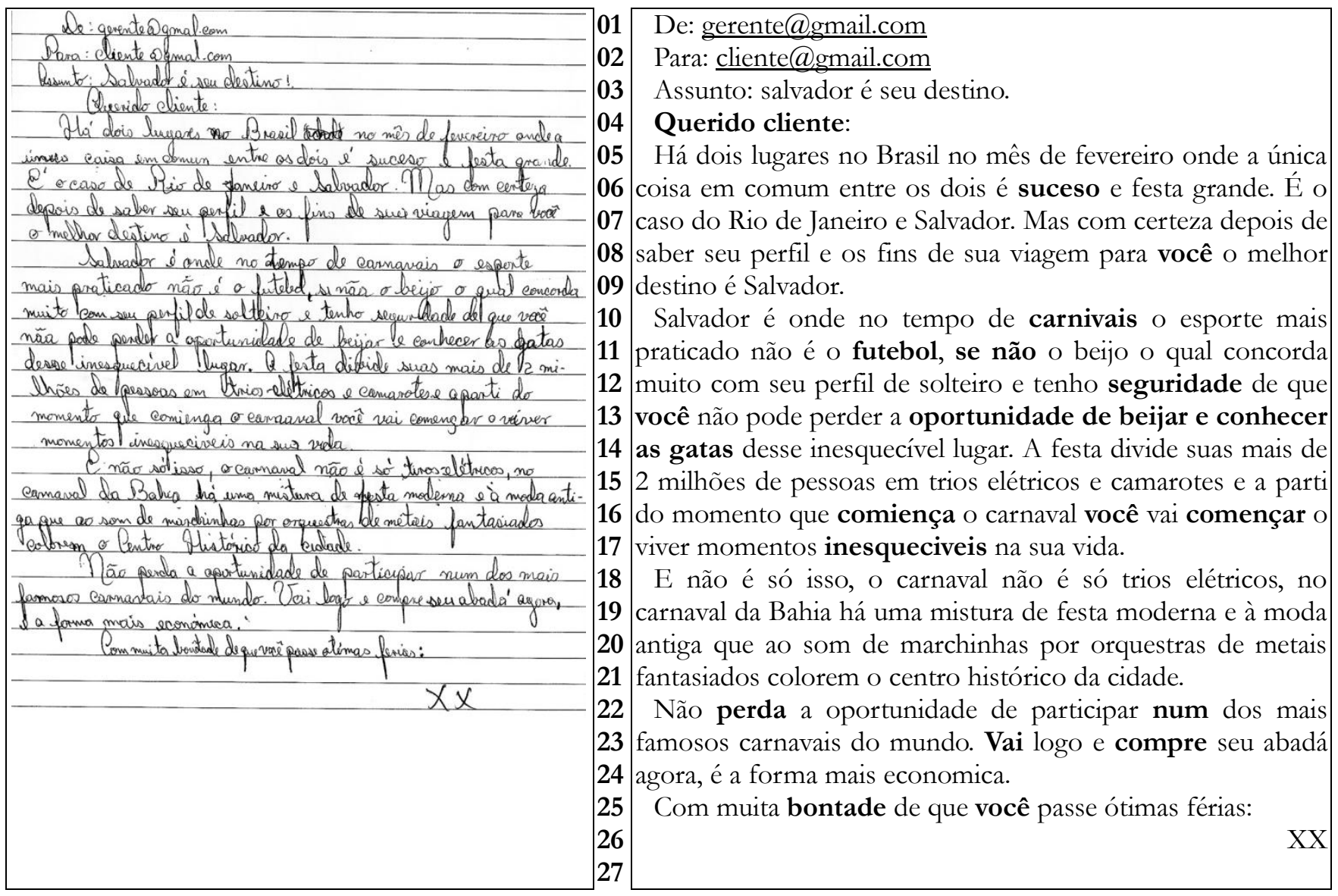

Podemos perceber no texto acima que o aluno conseguiu apresentar: A AÇÃO de produzir um texto do gênero e-mail, no qual dialoga com seu INTERLOCUTOR (interlocutor direto - o cliente), com o PROPÓSITO de dar resposta ao e-mail do cliente sobre o destino mais apropriado para passar o carnaval no Brasil. No entanto, não fez isso de maneira perfeitamente adequada para uma interlocução entre um gerente de uma agência de viagens e um cliente no Brasil.

No texto acima, o aprendente apresentou, além de problemas linguísticos, outro, talvez menos explícito, mas bastante impactante para o ensino-aprendizagem em turmas heterogêneas, que podemos configurar como uma experiência de transferência de uso que o aluno far de uma lingua-cultura dele para a língua-cultura alvo ou, ainda, da língua-cultura alvo para o seu texto escrito. Em ambos os casos, estamos falando de uma transferência de uso que não é bem 
aceita pelos falantes nativos do português no Brasil ${ }^{28}$. Esses problemas têm relação com aspectos de domínio das competências comunicativas (sociolinguística e pragmática).

Durante a nossa análise, observamos, por exemplo, que o vocativo, nos textos escritos pelos aprendentes, foi um dos marcadores que mais apresentou diferença de uso (ou influência de línguas-culturas). Muitas vezes, a opção por uma determinada forma de tratamento como Querido, Prezado, Caro, você etc., comumente utilizados em português, nos causou estranhamento porque, em certas situações, não era adequado, apesar de gramaticalmente correto, como podemos verificar no texto, acima, do A7.

$\mathrm{O}$ aluno optou por usar o termo querido cliente (04) na interlocução entre o gerente e o cliente, o que, em uma situação real de uso da língua, entre falantes do português L1 no Brasil, seria quase impossível, visto que a situação requer formalidade entre os interlocutores da ação. Além disso, o enunciador usa a pronome de tratamento você, que pelo menos em Belém, não costuma ser usado nesse tipo de situação: preferimos senhor. Além disso, o enunciador, como gerente de uma agência de viagens, não deveria interagir com seu cliente de maneira tão informal. $\mathrm{O}$ aluno se mostra à vontade para falar do beijo no carnaval de Salvador: "tenho seguridade de que você não pode perder a oportunidade de beijar e conhecer as gatas desse inesquecível lugar" (13-14). O que mostra descaso com regras de polidez, assim como uso inadequado do léxico. Percebe-se que o aluno já aprendeu alguns termos em português, mas não os utilizou apropriadamente em seu texto. O cuidado com o uso de algumas palavras merece atenção no ensino-aprendizagem de LE, pois "Os aprendentes terão, com o tempo, contato com falantes de diferentes proveniências. Antes de adotarem, eles próprios, formas dialetais, devem estar conscientes das suas conotações sociais e da necessidade de coerência e de consistência nessa adoção" (CONSELHO DA EUROPA, 2001, p.172), evitando assim, mal entendidos, falta de polidez etc.

A competência plurilíngue e pluricultural busca, entre outras, a tomada de consciência de uso de uma língua para que o locutor possa agir nela e explorar, além da competência linguística, a competência sociolinguística e pragmática, a fim de conduzir o aluno a perceber diferentes formas de uso daquela língua e estabelecer melhor relação com o outro.

\section{CONSIDERAÇÕES FINAIS}

O objetivo principal deste estudo foi investigar em que medida a habilidade de produção escrita do aluno foi desenvolvida e qual o impacto da heterogeneidade linguístico-cultural da turma no ensino-aprendizagem da PE. Em relação desenvolvimento da PE dos aprendentes, nossos dados nos mostraram que houve melhora considerável nos textos. Com o decorrer do trabalho, os aprendentes conseguiram ir além dos elementos paratextuais dos gêneros trabalhados (Cartas, e-mail, artigos de opinião etc., desenvolvendo com mais clareza os seus propósitos) do concordo com / discordo do autor, apresentando, em textos do tipo argumentativo, tese, argumentos e propostas de intervenção.

Os alunos se apropriaram das particularidades dos gêneros trabalhados (sobretudo de Carta do leitor) ao realizarem tarefas contextualizadas. Os assuntos atuais e globais, retirados de documentos autênticos, os levaram a se verem/imaginarem em situações reais de uso da língua (ao relacionarem os assuntos com as suas vidas), como atores sociais que cumprem tarefas com objetivo específico, realizando ações da vida real. O progresso que os alunos tiveram entre a primeira e a última produção escrita são indícios significativos de que esta pesquisa-ação pode ter favorecido a superação das dificuldades inerentes ao ensino-aprendizagem da PE. O resultado do nosso trabalho repercutiu no exame Celpe-

${ }_{28}$ Neste estudo, toda vez que nos referirmos ao Brasil, estamos falando, sobretudo, de nossa experiência como cidadãos de Belém-PA. 
Bras. Todos os aprendentes foram certificados, seis (em sete) com um desempenho muito bom.

Em relação ao impacto da heterogeneidade linguístico-cultural da turma no ensino-aprendizagem de $\mathrm{PE}$, percebemos nos textos escritos dos alunos que, no início do curso de PLE, de um modo geral, eles não dominavam a competência comunicativa (marcadores linguísticos de relações sociais, o léxico, as expressões de sabedoria popular, as regras de polidez etc.) no uso do português. Por isso, usavam bastante em seus textos o conhecimento que possuíam de suas línguas-culturas, o que impactava consideravelmente o ensino-aprendizagem, uma vez que se tratava de uma turma muito heterogênea do ponto de vista linguístico-cultural.

$\mathrm{Na}$ escrita, o impacto da heterogeneidade da turma foi observado a partir das diversas e diferentes influências das $\mathrm{L} / \mathrm{C}$ dos alunos nos textos. Isso nos causou dois tipos de problemas: um de ordem lexical e gramatical e outro de ordem mais linguageira e cultural. O primeiro tipo de problema não nos preocupou muito porque desaparecia à medida que o aluno ia dominando a língua alvo. Já os problemas de ordem linguageira e cultural nos deixaram mais atentos, pois o uso (culturalmente) inadequado que os alunos faziam da língua-cultura do português brasileiro em suas produções escritas, muitas vezes comprometia o texto como um todo. Daí nossa preocupação em não dissociar língua de cultura na proposta de elaboração de tarefas e, também, em "explorar", em sala de aula, a realidade vivenciada pelos alunos em seus países - o que favoreceu o trabalho que realizamos com a turma heterogênea.

Embora os primeiros resultados pareçam animadores, nada do que foi feito aqui deve ser tomado como definitivo e acabado. A pesquisa está apenas iniciada. Sabemos que ainda há muito que fazer. Nosso trabalho continua no âmbito do nosso Grupo de pesquisa de Ensino-Aprendizagem de Línguas-Culturas (GEALC) ${ }^{29}$.

\section{REFERÊNCIAS}

ABDALLAH-PRETCEILLE, M. Former et éduquer en contexte hétérogène: Pour un humanisme du divers. Paris : Anthropos, 2003.

BAKHTIN, M. Os gêneros do Discurso. In: Estética da criação verbal. Tradução de M. Pereira. 2. ed. São Paulo: M. Fontes, 1997.

BAGNO, M.; GAGNÉ, G.; STUBBS, M. Língua materna letramento, variação e ensino. São Paulo: Parábola, 2002.

BEHARES, L. E. Brasil-Uruguai: contribuição ao estudo da heterogeneidade linguísticocultural da fronteira sul. Diálogos Possíveis, Revista da Faculdade Social da Bahia. Salvador: Faculdade Social da Bahia, ano 2, v.3, n.1, 2003. p.29-45.

BÉRARD, E. Les tâches dans l'enseignement du FLE: Rapport à réalité et dimension didactique. Le Français dans le monde. La perspective actionnelle et l'appoche par les tâches en classe de Langue. Paris: 2009, p. 37- 43.

BILLIEZ, J. De la didactique des langues à la didactique du plurilinguisme: hommage à Louise Dabène. Grenoble: CDL-LIDILEM, 1998.

29 Coordenado por José Carlos Cunha. 
BRONCKART, J. P. Atividades de linguagem, textos e discurso: por um interacionismosócio-discursivo. Tradução de Anna Rachel Machado e Péricles da Cunha. São Paulo: Educ, 1999.

CONSELHO DA EUROPA. Quadro Europeu Comum de Referência para as Línguas: aprendizagem, ensino e avaliação. Tradução de Maria Joana P. do Rosário e Nuno V. Soares. Porto, Portugal: Edições Asa, 2001. Disponível em: <www.asa.pt/downloads/>. Acesso em: 30 maio 2013.

COSTE, D. Curriculum et pluralité. Études de linguistique appliquée, n. 98. Paris: Didier Érudition, 1995, p. 68-84.

COSTE, D. ; MOORE, D. ; ZARATE, G. Compétence plurilingue et pluriculturelle. Strasbourg: Conseil de l'Europe, 1997.

DABÈNE, L.; DEGACHE, C. (Ed.) Comprendre les langues voisines. RevueÉtudes de linguistique appliquée n. 106. Paris: Didier Érudition,1996.

LIMA, L. M. Reconhecer-se como brasileiro ao conhecer a heterogeneidade linguístico-cultural hispano-americana. Trabalhos de Linguística Aplicada, Campinas, $\mathrm{n}$. 50, 2011, p.45-53.

PESSOA, M. S. Marcas Socio-Linguístico-Culturais em aulas de Língua Portuguesa materna e Não-Materna no Portal da Amazônia. Revista Eletrônica da Associação dos professores de Português, v. 1, 2011, p. 1-21. Disponível em: < www.revple.net/documentos/RevPLE-artigo_M_Socorro_Pessoa.doc $>$. Acesso em: 30 maio 2013.

POMPEU, H.; CUNHA, J. C. O impacto do QECRL no ensino/aprendizagem da produção escrita em FLE. Belém. In: Congresso internacional de estudos linguísticos e literários na Amazônia, 4., 2013. Disponível em: http://www.4ciella.com.br/resumos.php?mod=7\&tipo=\&letra=H. Acesso em 13 abr. 2013.

POMPEU, H.; SOUSA, W. Aprendentesple: plataforma virtual no ensino-aprendizagem da produção escrita em português língua estrangeira - PLE. Belém. In: CONGRESSO INTERNACIONAL DE ESTUDOS LINGUÍSTICOS E LITERÁRIOS,4., 2013 (no prelo). Disponível em: http://www.4ciella.com.br/resumos.php? $\bmod =7 \&$ tipo=\&letra $=H$. Acesso em 13 abr. 2013.

ROULET, E. Langues maternelles, langues secondes, vers une pédagogie intégrée. Paris : Hatier, 1980.

VYGOTSKY, L. Pensamento e Linguagem. Edição eletrônica, 2002 [1947]. Disponível em: <http://www.ebooksbrasil.org/eLibris/vigo.html>. Acesso em: 01 jun.2012.

Recebido em 13/05/2014

Aprovado em 04/11/2014 